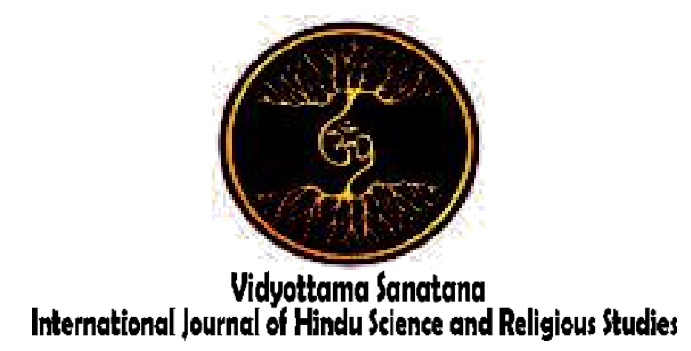

Vol. 2 No. 1 May 2018

\title{
Religious Harmony Among Senior High School Students Multicultural Education Case Study in the Cova-Lima District of East Timor
}

By:

Francisco Soares ${ }^{1}$, I Ketut Sudarsana ${ }^{2}$

${ }^{1}$ Universidade Da Paz Dili East Timor, ${ }^{2}$ Institut Hindu Dharma Negeri Denpasar

Email: ${ }^{1}$ __soares@gmail.com, ${ }^{2}$ iketutsudarsana@ihdn.ac.id

\author{
\begin{tabular}{|l|l|l}
\hline Received: November 11, 2017 & Accepted: May 10, 2018 & Published: May 31, 2018
\end{tabular}
}

\begin{abstract}
Harmony is a state where there is mutual understanding, unity, cooperation, peace and friendship among members who live together for a purpose of nation and state. In addition it can also mean that harmony is a state that reflects mutual understanding and agreement among members so as to create peace and harmony. Religious harmony is not the religious teachings blend in the sense of mixing up the religious teachings, but the harmony between different religious faiths. Religious harmony can be realized if there is a tolerance among believers of different faiths. The attitude of tolerance is no other way by controlling yourself in attitude toward others, so that others do not feel harmed or threatened. The attitude of self-control is of course not just coming from one party. This should be done by every believer of different religions.
\end{abstract}

Keywords: Harmony, Religious People

\section{Introduction}

Timor Leste is a large country whose people are consist of various tribes, cultures / customs and adheres to different religions or beliefs. The religious differences or beliefs held by the people of East Timor are guaranteed by the Constitution and further elaborated on the National Education System. In the current globalization era, religious harmony has begun to decline, because the 
people of East Timor tend to be more concerned with themselves or groups than the nation and country. It can be seen from the daily life of the community, where there are many conflicts between groups that causes trivial.

For the sake of realizing the harmony of life between religious believers is needed an effort from various parties. In order to foster and develop an attitude of tolerance among religious believers, for the sake of religious harmony, as citizens of Timor Leste need to avoid the following attitudes:

a. Excessive fanatical attitude, ie attitude that does not recognize and appreciate other religions, even hostile.

b. Attitude of mixing various religious teachings and beliefs.

c. Ignorant attitude towards believers of other religions or beliefs.

Living in harmony in interfaith communion is maintained and cultivated from school to religious organization groups, as well as religious lectures, that harmony is essential for the common goal of nationhood and statehood. School is a formal educational institution that runs a government program to advance its citizens both in its science and mental attitude. School is a leading institution that can be used to instill as early as possible concepts of harmony between religious, nation and state. High school is a public school whose students consist of various tribes, and embrace different religions or beliefs. From the very diverse circumstances of both ethnic diversity, cultural diversity and religious diversity it embraces, the Principal's commitment to assist the government in keeping the harmony of the faithful is set forth in the annual school program that provides or provides as much as possible the teachers of each religion or the flow of trust shared by the students. In addition to providing faculty, high schools often hold religious activities attended by all students, among others: Welcoming Christmas and New Year (for Christians) or Hari Raya Maulud Nabi (for Muslims). This awareness encourages authors to think systematically in relation to the issue of religious harmony in secondary schools in Cova-Lima District from the perspective of multicultural education to be examined. Departing from the above thinking, the writer felt compelled to conduct research in secondary schools in Cova-Lima District.

This research is a mirror for the writer in a broad sense, both writers as educators who teach the subjects of Religious Education, who bear the responsibility for Religious Harmony programmed by the government. Through introspection, it is expected to all religious people to understand the teachings of religion or beliefs, and eliminate the feeling that the religion they adhered to is the best religion and view the other religions are less good. All Religions or beliefs are basically good, which sometimes mistakenly understood by the people themselves. This is because humans are generally not perfect.

The younger generation who sit in school, especially in high school in the CovaLima District must be saved, mentored and nurtured in order to face the advancement of technology and information flow by not sacrificing the noble values of the nation. One aspect of coaching that can address the challenges that are and will be faced is by fostering spiritual education. It is expected that in the coaching will be born humans who 
can love each other, polite, honest, cooperative and devoted to God Almighty.

\section{Method}

The research method is an attempt to find develop and examine the truth of a knowledge. The method is in addition used as a tool to draw conclusions, explain and analyze problems, but also used to solve problems. The theories used to solve the problem are as follows: structural functional theory and value theory. The methods used for data collection include observation, interview, bibliography, documentation. Data analysis is done through qualitative descriptive technique.

\section{Result and Discussions}

\subsection{The Form of Religious Harmony among the Students of High School in Cova-Lima District}

High school in Cova-Lima district is a upper secondary public school established almost throughout the territory of Timor-Leste. These schools are open to the public and are located in developing areas so that their students are composed of various tribes, cultures / customs, and religions or beliefs. Differences in ethnic, cultural / customs, religions and beliefs held by high school students in the CovaLima district are evidence that high school in Cova-Lima district is a school of multicultural students.

Tribal differences, cultures / customs, religions or beliefs of high school students In Cova-Lima district is not an obstacle to a relationships among students, as well as curricular activities or extra-curricular activities. The Principal's wisdom to celebrate the religious holidays of each religion held by the students in the school is welcomed by the students and their respective religious teachers. Students from different religious backgrounds in Cova-Lima district mingle closely in carrying out the celebration of religious day. For students to understand each other, the purpose of celebrating religious day is directe to create a sense of togetherness among students' with different culture background in the high school of Cova-Lima district.

Recognizing the diversity of tribes, cultures / customs, religions or beliefs held by their students, the Headmaster and his teachers and employees in the high school of Cova-Lima district are expected to attend religious ceremonies as carefully as possible to maintain harmony among fellow religious followers in the high school of Cova-Lima district. Headmaster gives freedom to Religious teachers in the high school of Cova-Lima district to celebrate religious ceremonies as much as possible involving students of other faiths.

It turns out that all activities conducted together very useful for all students in understanding the meaning of harmony itself, there is no conflict ever happen between students who trigger based on tribe, culture, or religion. Harmony itself is seen from the cooperation between the principal with the teacher, teachers with teachers and teachers with their students. So, the high school activities in Cova-Lima district are done everyday including Sundays.

Each teacher is very influential on all students as an example in togetherness and role model in implementing the school programs that have been determined 
especially the Islamic religious teachers, Catholic Religion, Protestant Religion and Hinduism together to foster and guide their students to respect each other, teachers and all school staffs. This has been well implemented in the high school of Cova-Lima district which is manifested by holding celebrations of religious holidays such as:

Christmas and New Year Celebrations by Christian and Kotolic children as a committee along with staff of student internal organization under the supervision of religious teachers, Students and teachers and staff at High school level in Cova-Lima district. The ceremony was preceded by a ceremony according to Christianity after which it was followed by a public lecture entitled Jesus the Most Compassionate. After the official event was finished, all participants congratulated the students and teachers who are Christian and Catholics, and then they have dinner together.

Then it was the turn of the Hindu children celebrating Nyepi Day held at the National Vocational Education Society in Cova-Lima district attended by all high school students and teachers and staff, all high school students in Cova-Lima district with teachers and employees. The opening ceremony was filled with a public lecture entitled Self Introspection in Togetherness toward a Better Life, followed by dinner together. After the lecture was finished, all the Hindu students and teachers and their staff held a prayer meeting.

The next opportunity is the children who are Moslems who celebrate the Feast of Maulud Nabi with the committee of Muslim children and members of the
International Student Organizations coordinated by Islamic religious teachers in cooperation with students attended by all students as well as teachers and employees of the high school. The event was preceded by a ceremony according to Islam then continued with a public lecture entitled Prophet Muhammad a Wise Leader. After the lecture done, they have their dinner together.

With the implementation of the religious celebrations above, all high school students directly have been able to maintain the inter-religious harmony viewed from the multicultural aspect of their students. This is the form of religious harmony among the high school students in Cova-Lima districts, regardless of their ethnic, racial or religious differences.

\subsection{The Effect of Religious Diversity on HighSchool Students' Interaction in Cove-Lima District}

The policy of high school headmaster in Cova-Lima District which aims to provide understanding of religious harmony in the school environment is welcomed by all students. In general, every teacher feels assisted by the policy in the teaching and learning process that is held, let alone the religious teacher, the civic education teacher, the character teacher has no difficulty in transferring his knowledge to his students, because the subjects are touching directly to religious harmony in the middle school environment, district of Cova-Lima in particular, in the wider community. By understanding the meaning of the differences that exist for greater togetherness, every teacher in the Cova- 
Lima district high school can set an example in overcoming differences. Teachers and employees at the high school of Cova-Lima districts are assisting their students to create a harmonious, happy and secure atmosphere in the learning process together.

This policy is also appreciated by all students in every school activity. All students feel comfortable and secure in following the learning process without any significant disturbance, although there differences in the tribe, customs, culture, religion or beliefs. Each group of students in the high school of Cova-Lima district is treated fairly so the difference is a meaningful learning in understanding togetherness for the students themselves.

Teachers and employees in the high school of Cova-Lima district continuously assist the students to get a good understanding of the meaning of harmony between religious communities. So, the impact of religious differences held by students is not an obstacle to interact among college students, or among students, teachers and employees.

\subsection{Factors Influencing the Religious Harmony among High School Students in Cova-Lima District}

The implementation of religious harmony among people in the High School of Cova-Lima district in principle can be categorized as stable and steady because it is supported by several factors or elements, those are:

\section{a. Teachers}

The teacher is a noble profession, whose every behavior is highlighted by society, both from appearance, speech / language and deeds. Ideally a teacher should appear clean authoritative, soft spoken words, and can provide good example for children in their care and for social community. In addition as already mentioned, the teacher must also be able to develop himself, increase knowledge and follow the progress of existing technology, so the prestige and exemplary of a teacher still attached to him.

In conveying the religious subject material that contains the guidance of absolute truth values that are often boring for the students to listen, a teacher should be able to anticipate the method of delivering the material in order to be pleasant but not out of the concept of the material delivered. Provide examples in present life that are relevant to the material presented, so that the delivery of the material can be easily understood. Submission of material with more examples in daily life greatly helps students to more quickly understand the material delivered and the purpose of the material delivered. Moreover, a teacher can insert jokes that have something to do with the material presented. It will create a pleasant situation in the learning process so that the learning objectives easily and quickly can be achieved. Words of praise issued by a teacher are very meaningful to students who have completed their duties, and ask nicely to students who have not finished doing the task and understand the difficulties or problems that have been faced. Giving consequences for not completing the task is still done according to the level of error. The anger of a teacher is the anger of the profession not the anger of the person, so also the consequences 
given by a teacher are learning consequences. Thus can be understood by the students why they are praised or given consequences by their teacher.

The role of teachers is crucial in the context of creating religious harmony and participating in assisting the tasks of the government of Timor Leste, such as striving for the stability and national resilience in fostering the Three Harmony of Religious Life, those are:

1) Internal harmony of the religious community; it means fostering unity of life among the fellow believers. This has been done by each student, as the responsibility of their respective teachers.

2) Harmony between religious people means: to foster mutual respect among believers of a religion with other believers of other religions.

3) Harmony among religion and the government which means; the government is very aware of the freedom of its people to embrace the religion or beliefs and ensure the implementation of religious worship according to their respective religions. The right to freedom of religion is believed to be an essential right of every citizen guaranteed by the Constitution. Thus the government serves as the foster father of religious counseling. The leading base in the development of religious people is formal education in schools, in asram groups or pesantren who can support the achievement of national development goals, especially in the mental and spiritual fields of the nation's next generation. Based on the above reference teachers should be able to lead their students to make social contacts in order to grow a sense of tolerance, love, mutual respect for each other among religious people.

\section{b. The relationship among students}

As outlined in the religious teachings embedded in each of the areas of religion expressed above, it is reflected that High School students in Cova-Lima districts in principle can establish a relationship with their colleagues, this is reflected in routine execution such as extra curricular activities, the election of the organizers of Internal Student Organization and its inauguration, as well as other activities that require good cooperation among the students involved.

All activities that are charged to him will be completed well as expected, and require seriousness and high dedication among students as well as adequate ability and direction or guidance for teachers who are assigned to accepting him. This cooperation is certainly based on the awareness of the students themselves in an effort to create an atmosphere of harmony, peace, security, and harmony among religious students in the high school of Cova-Lima district. The harmonious relationship of high school students in Cova-Lima district may also be caused by economic factors that most of them are people with low to middle economic capability. The presence of this similar 
condition makes the social relationships run well.

The relationships of High School students in Cova-Lima districts both in school and out of school are very good, it can be seen that the students attending extracurricular activities outside school hours together according to their hobby or skill they have. This relationship can be done because every student no longer sees differences of tribe, culture / customs, religion in carrying out daily activities that have something to do with school activities.

\section{c. The relationship between high school students and school staffs in Cova-Lima district}

The existence of employees is very helpful for students in the administrative matters necessary for the successfulness of teaching and learning activities in the classroom. School staffs and student relationship is a mutually beneficial relationship, if it can be maintained properly, as in the acceptance of new students, then students who join the internal organization of students is very helpful in the work of school staffs and internal organizations of students is very helpful in the administration of administration documents for junior students. Every year, the members of the high school student organization in CovaLima district help their school staffs and teachers in the new recruitment with high interest and awareness as in their own home. they helped promote high school to their juniors who are still in junior high school. This kind of relationship will continue to be maintained because it is based on a sense of belonging, love for the school where they get knowledge for their future.

\section{d. The relationship between students and teachers}

Student relationships with the teachers take place very closely as if they were their parents. The relationship are very clear among them in their classroom relationship as a tutor or teacher of the subject so that the purpose of teaching and learning process can take place properly. Students as subjects in teaching and learning process that accompanied by the subject teacher as a mentor, the relationship is expected to be communicative in carrying out the teaching and learning process. Teachers should be able to appear as a model for their students so that they can be exemplified in their appearance, speech, and behavior, which are expected to encourage and motivate their students to learn better to achieve the desired goals. The example of a teacher is needed in order to more easily transfer the subject matter to the students, and the students are happy to receive the teaching. This kind of relationship will further ensure the outcome of the learning process to better match what is programmed.

The relationship of teachers and students outside the classroom but still around the school environment is a relationship as a child and his parents. This relationship can take place well, if the teachers take the time to serve the complaints of their students beyond the teaching and learning process. The feelings of the students, whether in 
relation to their social relationships in school and their social relationships at home, may in some cases affect their concentration in accepting classroom learning.

The interaction between the student and the teacher outside the school (not the learning process) is a good opportunity for a teacher to include learning motivations that can be done on the sidelines of the conversation. Usually a student is more easily directed or motivated spirit of learning if the student is willing to interact with his teacher outside the teaching and learning process. High school students In Cova-Lima district have a very close relationship with the teachers outside the teaching-learning process, because every teacher at the high school Di Cova-Lima district wants to spend his time serving the complaints / problems his or her students are facing as well trying to provide the best solution for the students.

This kind of relationship is the strength of its own high school At CovaLima district to survive until now still trusted by the community as a school for his children to study. This kind of teacher approach can also be used to deal with students who are not formally organized, so special approaches outside of the teaching and learning process are needed both at school and outside school which is still a school activity.

Teacher approach to students when conducting activities outside school is a good strategy because the students will not feel afraid or awkward either in conveying the problems they are facing or in receiving advice or discourse that can make the student become better than before. Such a relationship is still maintained until now in the the high school of Cova-Lima district.

\section{Conclusion}

High school students' ethnic, culture, or religious diversity in CovaLima District is not a barrier for children to celebrate religious festivals together with joy and mutual respect for one another. The form of togetherness is an implementation of the harmony of religious life in the diversity of tribes, cultures, customs, and religions. The teachers support the school programs that facilitate the students to celebrate the religious festival so that the theory conveyed in the classroom related to harmony can be practiced in a real life, especially regarding the issue of religious harmony in the middle school neighborhood of Cova-Lima District (a review in the perspective of multicultural education).

\section{References}

Andersen, (1994). Multicultural and Intercultural Studies, in Teaching Studies of Society and Environment (ed. Marsh,C)Sydney: Prentice-Hall.

Bielefeldt, T. (2011). Talking Points on World Tolerance - The Role of Education Human Rights Council: panel discussion on promotion of tolerance. Retrieved 26th July 2012 from:

http://www2.ohchr.org/english/bodies/ hrcouncil/docs/16session/A-HRC-1653.pdf, 
Dumteeb, N. (2009) Teachers' questioning techniques and students' critical thinking skills: English language classroom in the Thai context. ProQuest Dissertations and Theses. Retrieved November 26, 2012 from: http://udini.proquest.com/public/

Duron R., Limbach, B, and Waugh W. (2006). Critical thinking framework for any discipline International Journal of Teaching and Learning in Higher Education 2006, Volume 17, Number 2, 160-166 http://www.isetl.org/ijtlhe/ ISSN 1812-9129

Min, K. K. (2017). The Value Of Saemaul Undong: South Korea Community Character Booster. Vidyottama Sanatana: International Journal of Hindu Science and Religious Studies, 1(1), 46-52.
The International Service for Human Rights (2012) Talking points on world tolerance - The Role of education. Human Rights Council: Panel discussion on promotion of tolerance sees less divisive debate. Retrieved 26th July,

2012 from:http://www2.ohchr.org/english/b odies/hrcouncil/docs/16session/AHRC -16-53.pdf,

Wamaungo, J. A. (2017). Character Education Across Cultures: How Uganda Develops Students Desired Characters In Inclusive Perspective. Vidyottama Sanatana: International Journal of Hindu Science and Religious Studies, 1(1), 14-20. 